possibly a deficiency phenomenon and responded rapidly to vitamins, but for the scleral tesion no treatment availed. There was no sign of uveal inflammation or vascularization, and the condition was due to a degeneration of the sclera causing perforation and subsequent hypotony.

\title{
REFERENCES
}

1. Rones.- Senile changes and degeneration in the human eye. Amer. Ji. Ophthal., Vol. XXI, No. 3, p. 243, 1938

2. DuKf-ELdER.-Text-boòk of Ophthalmology. Vol. II, p. 2066, 1946.

3. GRAves.-Bilateral mesial superficial deficiency of sclera. Brit Jl. Ophthal., Vol. XXI, p. 534, 1937.

4. - Bilateral mesial superficial deficiency of sclera-scleral plaques. Brit. Jl. Ophthal., Vol. XXIII, p. 191, 1939.

5. Bilateral mesial deficiency of the sclera-scleral plaques. Brit. Jl. Ophthal., Vol. XXV, p. 35, 1941.

6. Culler.-The pathology of the scleral plaque . Brit. Jl. Ophthal., Vol. XXIII, p. 44, 1939.

7. VAN DER HOEVE.-Scleromalacia perforans. Arch.f. Ophthal., Vol. XI, p. $111,1934$.

8. ARKI.E and INGRAM.-? Scleromalacia perforans. Trans. Ophthal. Soc.U.K., Vol. LV, p. 552, 1935.

9. VerhoEFF and KING.- Scleromalacia perforans (as referred to by Culler). Trans. Amer. Ophthal. Soc., 1938.

\section{TECHNIQUE OF IRIDENCLEISIS*}

BY

\section{WEEKERS and R. WEEKERS \\ LIÉGE, BELGIUM}

IN various papers ( 1 to 11 ), since 1931 , in collaboration with our colleagues Hubin, Fanchamps, Bonhomme, Heintz, Mathieu, Roussel, Gérard, Thibert, we have maintained that iridencleisis is the best anti-glaucomatous operation. It reduces the level of intra-ocular pressure more than any other operation, it is the least mutilating, and it can be used in all types of glaucoma.

Because traumatic iris prolapse may be followed by hypertension rather than hypotension, it is important that the technical details of iridencleisis be discussed. The placement, length and direction of the scleral incision; involvement of iris and ciliary body in the scar; changes in the anterior chamber angle and Schlemm's canal; all may influence the tensional results of surgical intervention.

Inasmuch as various methods of performing iridencleisis are not

* Received for publication, June 5, 1948. 
equally effective, it is necessary to discover that which affords the most consistent and lasting results, which is the least traumatizing, and that which bears the least complications.

The technique described below has been used now for the last 18 years in hundreds of cases, substantially without modification. It is so simple that it is difficult to imagine any way of making it still easier.

\section{Pre-operative preparation}

One of the important advantages in this method of performing -iridencleisis is that prolapse of the iris, during the operation, is spontaneous. Other methods, particularly that of Holth, depend on the manoeuvre of catching the iris with a hook or with forceps.

Because either a very miotic pupil or a very dilated one may prevent this spontaneous prolapse, the use of miotics is discontinued on the evening before surgery. Even when the intraocular pressure in the fellow eye may be normal, this eye is kept under miotics as a preventive measure.

On the evening before surgery and on the day of surgery a solution of penicillin ( $1,000 \mathrm{U}$. per c.c.) is instilled frequently in both eyes.

\section{Anaesthesia}

One hour before operation, the patient is given a subcutaneous injection of 0.5 c.c. of scophedal (eucodalscopolamine). Just before surgery a retrobulbar injection of 1 c.c. of a mixture of 4 per cent. novocaine and one drop of $0 \cdot 1$ per cent. epinephrine is given. The epinephrine tends to dilate the pupil but has the advantage of reducing intra-ocular pressure.

In order to avoid the mydriasis caused by cocaine, a 2 per cent. solution of butelline is instilled for topical anaesthesia. A few drops of 2 per cent. novocaine without epinephrine are injected into the conjunctiva of the upper fornix. It is advisable to avoid injection. near the limbus because of consequent oedema.

\section{Operation}

(a) Dissection of the Conjunctiva (Figs. 1 and 2) $-\mathrm{A}$ tension suture is placed in the conjunctiva at twelve o'clock, about $15 \mathrm{~mm}$. above the limbus. The assistant can raise the conjunctiva away from the tendon of the superior rectus muscle by means of this suture.

The incision is begun above with scissors and penetrates to the sclera to insure a thick flap. A thin flap is thought to be a cause 
for late infections reported by many using such filtering operations as the Elliot trephining procedure.

The incision may be continued with a cataract knife nasally and temporally to the horizontal limbus. It is helpful to fixate the eyeball by means of a snap forceps on the tendoninous insertion of the superior rectus muscle. This makes dissection of the flap easier and more precise and prevents tearing of the conjunctiva.

The dissection is carried into the limbus from 10 around to 2 o'clock, far enough so that corneal tissue becomes visible. When the flap is completed it should drape over the cornea spontaneously.

(b) Incision in the Eyeball (Figs. 2 and 3).-Whereas for dissection of the conjunctival flap the cataract knife was used in a tangential manner, for the incision into the eyeball it is applied perpendicularly to the globe. Firm fixation of the eyeball is maintained by the assistant. After marking, just within the limbus at 12 o'clock, the incision is completed with one bold stroke of the knife. As a result of the sudden opening of the eyeball, aqueous spouts through the wound, carrying with it the iris. This spontaneous prolapse occurs even in the presence of posterior synechiae or even in the, presence of a completely secluded pupil. The sudden rush of aqueous tears any adhesions present.

If the operator is too cautious in making the incision, aqueous escapes slowly and spontaneous iris prolapse may not occur. However; light pressure on the eyeball in a nearby area is usually sufficient to prolapse the iris into the wound so that it can be grasped with a forceps.

(c) Tearing of the Iris (Figs. 3, 4 and 5).-The iris prolapse appears in the incision as a tiny ball. Its summit is seized with two iris forceps, one on each side. A slight horizontal pull then tears the iris into two fragments. They are merely separated from each other without any upward pulling which might raise the level of the pupil.

(d) Conjunctival suture (Fig. 6).-Immediately after the iris flaps are dropped, the conjunctiva is gently put in place and the fixation forceps is removed. Thus iris tissue has been exposed only for a fêw seconds. As the assistant raises the tension suture originally placed in the conjunctiva, it is an easy matter for the surgeon to place initial sutures of plain catgut on either side. Closure of the conjunctival wound is completed with additional sutures laterally.

Penicillin solution is instilled and a uniocular dressing is applied. 


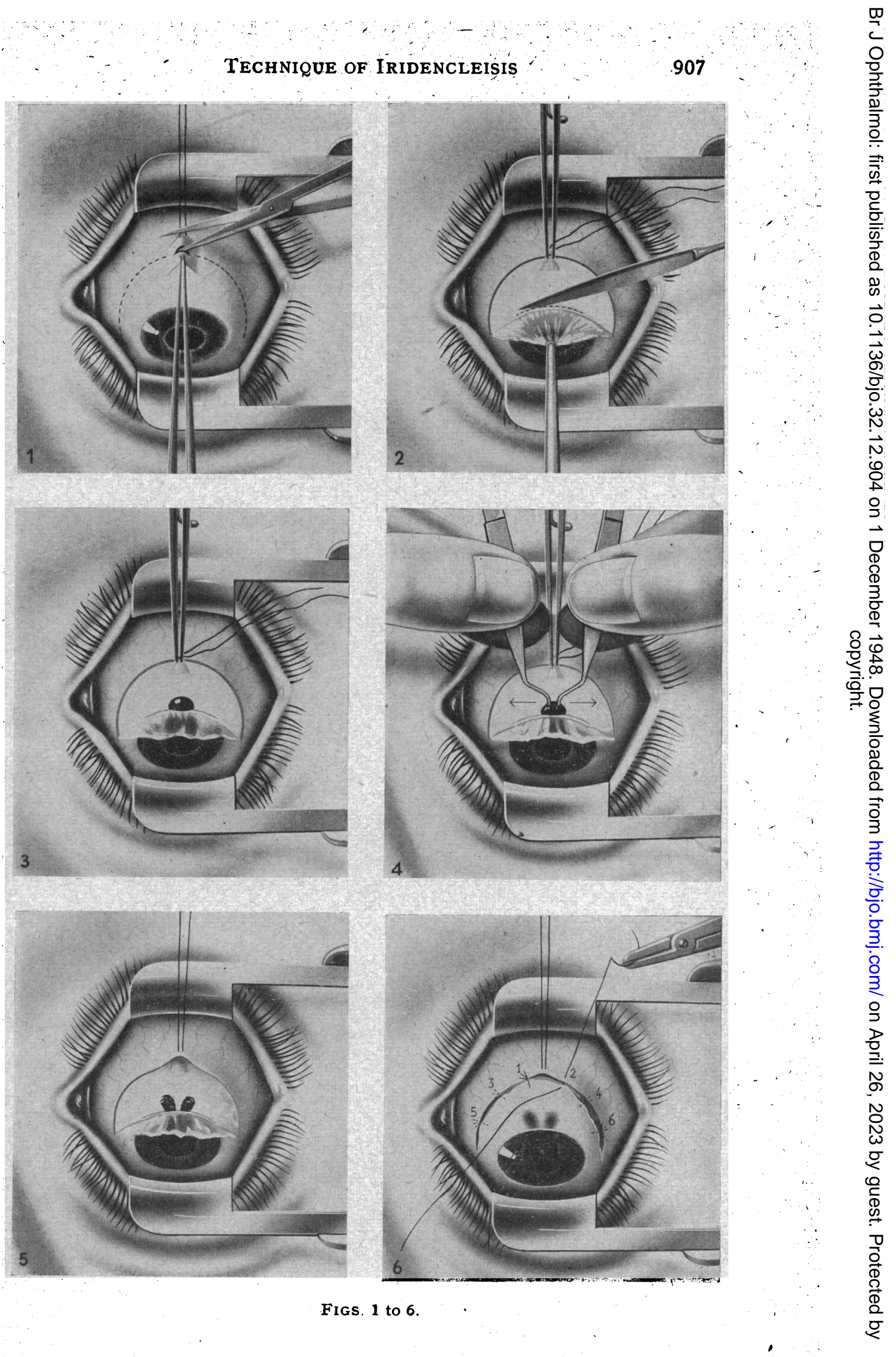


L. WEEKERS and R. WEEKERS

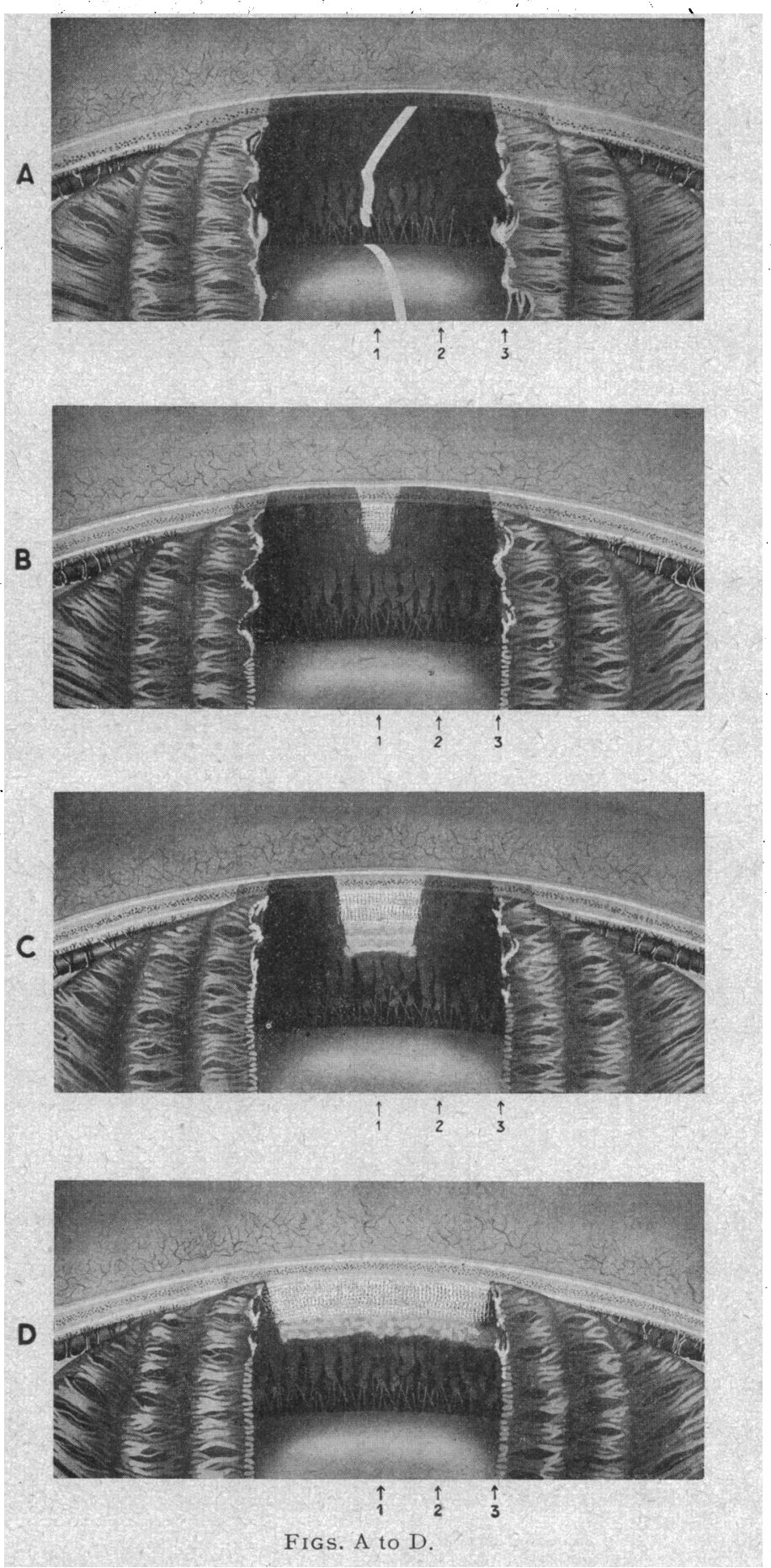




\section{Post-operative care}

The dressing is removed after 48 hours but is always replaced at night for an additional 5 days.

Atropine is instilled twice daily for 2 days as soon as the anterior chamber is formed, usually within 2 or 3 days. Penicillin solution is also instilled three times a day. It is noteworthy that it is exceptional for even slight posterior synechiae to develop, a substantial advantage over the Elliot trephining which is frequently complicated by an iritis.

\section{Gonioscopic study}

Gonioscopy on operated eyes is instructive in that it demonstrates anatomical details of healing, evaluation of operative technique, and affords information as to the mechanism of action of iridencleisis. François, in his paper on gonioscopy, made special mention of findings in cases operated on by our method $\left({ }^{12}\right)$.

Our gonioscopic observations were carried out according to Goldmann's technique with the Haag-Streit slit-lamp and a contact lens fitted with a mirror. For the sake of clarity the figures. we show below are schematic.

The most frequent gonioscopic picture seen is shown in Fig. A. To the right and left, the anterior face of the iris is visible. Displacement of its fibre pattern shows that it is drawn upward, the iris is also drawn forward because the wound is anterior to Schlemm's canal. Such warping of the plane of the iris indicates that the incision was properly placed. Its absence indicates that the incision was placed-too far back. The prolapsed iris outside the globe is not visible.

In the centre some of the posterior surface of the iris can be seen. It has a characteristic deeply pigmented velvety appearance even in subjects with a lightly coloured anterior surface. The angle of the anterior chamber above cannot be seen because of the position of the iris pillars. Lower down, the ciliary processes, zonule, and lens can be seen clearly.

Fig. B. shows a picture frequently seen but slightly different from that in the previous figure. Here, in the course of operation, lateral tension was sufficient to rupture the radial fibres of the iris almost to the root. A small area of grey discoloured atrophic tissue lies at the base of the tear and is nearly always easily seen. At this point where iris tissue is attached to the limbal wound, it forms two pillars which are the lateral sides of a triangle with its apex at the root of the iris. 
The picture demonstrated in Fig. C. is less frequently seen. The tear in the iris is more complete, going beyond the root to form a very slight iridodialysis, consequently the iris pillars are more widely separated.

In Fig. D. it is evident that excessive tension on the iris pillars during operation caused an iridodialysis along the whole base of the coloboma. This is the exceptional finding.

\section{REFERENCES}

1. WeEKERS, L and HUBIN, R.-Arch.d'Ophtal., Vol. XLVIII, p. 186, 1931.

2. WeEkERS, L.-Arch. d'Ophtal., Vol. XLVIII, p. 593, 1931.

3. - Arch. d'Ophtal., Vol. LIII, p. 166, 1936.

4. WeEkERS, L. and FANCHAMPS, J.-Arch. d'Ophtal., Vol. I, p. 585, 1937.

5. Weekers, L.-Bull: Soc. Ophtal, Paris. Nancy, 16 juin, séance consacrée au traitement médical du glaucome. 1939.

6. WeEkers, L. and Bonhomme, F.-Ophthalmologica, Vol. XCIX, p. 180, 1940.

7. WeEKERS, L.-Bull. Soc. belge d'Ophtal., février, 1948.

8. WeEkers, R. and HeINTz, A.-Bull. Soc. belge d'Ophtal., février, 1948.

9. WEEKERS, R. and GERARD, R.-Bull. Soc. belge d'Ophtal., février, 1948.

10. WeEkers, R. and Mathieu, P.-Bull. Soc. belge d'Ophtal., février, 1948.

11. Roussé L, F.-Bull. Soc. belge d'Ophtal., février, 1948.

12. François, J.-Bull. Soc. belge d'Ophtal., février, 1948.

\section{CARBONIC ANHYDRASE AND CATARACTA LENTIS*}

BY

\section{A. BAKKER}

GRONINGEN

Problems concerning the genesis of cataract have engaged the attention of innumerable investigators throughout centuries. Measures, taken against the sequels of cataract are as old as mankind and in our days have reached a high degree of perfection. Preventive measures, however, had only success under special, limited circumstances. Cases in which we succeed in protecting individuals who may be considered as to be predestined to acquire cataracts are not very numerous, but in spite of the limited possibilities, benefits are great. Some examples may elucidate this. By the use of adequate goggles we are able to protect people against the injurious effect of radiant energy. When diseases of the thyroid gland make operation necessary, we can prevent lens opacities by taking precautions not to injure the parathyroid glands. When, however, it is not possible to avoid injury to these glands, develop-

- Received for publication, February 4, 1948. 